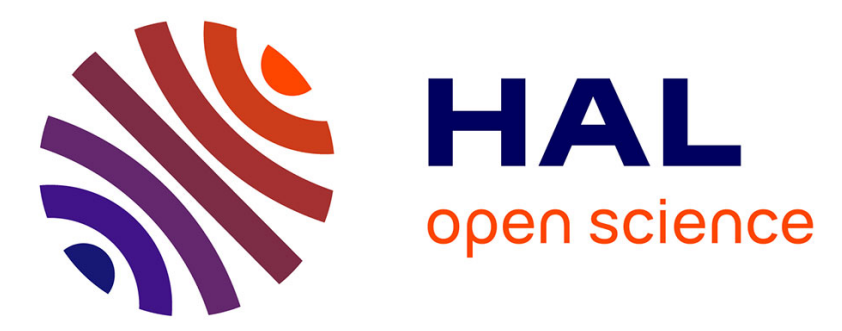

\title{
Dietary Transfer of Fluoranthene from an Estuarine Oligochaete ( rubroniveus) to Grass Shrimp ( ): Influence of Piperonyl Butoxide
}

\author{
Ab Filipowicz, Je Weinstein, Dm Sanger
}

\section{- To cite this version:}

Ab Filipowicz, Je Weinstein, Dm Sanger. Dietary Transfer of Fluoranthene from an Estuarine Oligochaete ( rubroniveus) to Grass Shrimp ( ): Influence of Piperonyl Butoxide. Marine Environmental Research, 2007, 63 (2), pp.132. 10.1016/j.marenvres.2006.06.005 . hal-00562956

\section{HAL Id: hal-00562956 https://hal.science/hal-00562956}

Submitted on 4 Feb 2011

HAL is a multi-disciplinary open access archive for the deposit and dissemination of scientific research documents, whether they are published or not. The documents may come from teaching and research institutions in France or abroad, or from public or private research centers.
L'archive ouverte pluridisciplinaire HAL, est destinée au dépôt et à la diffusion de documents scientifiques de niveau recherche, publiés ou non, émanant des établissements d'enseignement et de recherche français ou étrangers, des laboratoires publics ou privés. 


\section{Accepted Manuscript}

Dietary Transfer of Fluoranthene from an Estuarine Oligochaete (Monopylephorus rubroniveus) to Grass Shrimp (Palaemonetes pugio ): Influence of Piperonyl Butoxide

AB Filipowicz, JE Weinstein, DM Sanger

PII:

S0141-1136(06)00173-5

DOI: 10.1016/j.marenvres.2006.06.005

Reference: MERE 3062

To appear in:

Marine Environmental Research

Received Date:

14 July 2005

Revised Date:

20 July 2005

Accepted Date:

20 June 2006

Please cite this article as: Filipowicz, A., Weinstein, J., Sanger, D., Dietary Transfer of Fluoranthene from an Estuarine Oligochaete (Monopylephorus rubroniveus) to Grass Shrimp (Palaemonetes pugio ): Influence of Piperonyl Butoxide, Marine Environmental Research (2006), doi: 10.1016/j.marenvres.2006.06.005

This is a PDF file of an unedited manuscript that has been accepted for publication. As a service to our customers we are providing this early version of the manuscript. The manuscript will undergo copyediting, typesetting, and review of the resulting proof before it is published in its final form. Please note that during the production process errors may be discovered which could affect the content, and all legal disclaimers that apply to the journal pertain. 


\title{
Dietary Transfer of Fluoranthene from an Estuarine Oligochaete (Monopylephorus rubroniveus) to Grass Shrimp (Palaemonetes pugio): Influence of Piperonyl Butoxide
}

\author{
AB Filipowicz ${ }^{1 *}, \mathrm{JE}$ Weinstein ${ }^{2}$ and DM Sanger ${ }^{3}$ \\ ${ }^{1}$ College of Charleston, Grice Marine Laboratory, 205 Fort Johnson Road, Charleston, \\ SC 29412 \\ ${ }^{2}$ The Citadel, Department of Biology, 171 Moultrie Street, Charleston, SC 29409 \\ ${ }^{3}$ South Carolina Sea Grant Consortium, 287 Meeting Street, Charleston, SC 29401 \\ *Corresponding Author: \\ phone: (518) 486-7512 \\ fax: (518) 473-2464 \\ email: amyfilipowicz@hotmail.com \\ Present address: New York State Department of State, Division of Coastal Resources, 41 \\ State Street, Albany, NY 12231
}

\begin{abstract}
The objective of this study was to determine the potential for dietary transfer of sedimentassociated fluoranthene from tubificid oligochaetes (Monopylephorus rubroniveus) to grass shrimp (Palaemonetes pugio). Grass shrimp, either in the presence or absence of sublethal waterborne concentrations of the metabolic inhibitor, piperonyl butoxide (PBO), were fed fluoranthene-dosed oligochaetes for 5 days. All grass shrimp bioaccumulated fluoranthene; however, bioaccumulation was $3 \mathrm{X}$ higher in the presence of PBO. Trophic transfer coefficients (TTCs) were 0.02 and 0.01 in the presence and absence of $\mathrm{PBO}$, respectively. Following the 5-day accumulation period, shrimp in both treatments were allowed to depurate for 3 days. Depuration rates were significantly higher in PBO-exposed shrimp. These results demonstrated that sediment-associated fluoranthene can be transferred through the diet from oligochaetes to grass shrimp, and the presence of PBO enhanced fluoranthene bioaccumulation. However, the comparatively low TTCs suggest that biomagnification of fluoranthene in estuarine food webs is low.

Keywords: bioaccumulation, cytochrome P-450, dietary transfer, fluoranthene, Monopylephorus rubroniveus, Palaemonetes pugio, polycyclic aromatic hydrocarbons, piperonyl butoxide
\end{abstract}

\section{Introduction}

Polycyclic aromatic hydrocarbons (PAHs) are common contaminants in estuarine ecosystems. Primary sources of PAHs in these systems include the combustion of fossil fuels and direct petroleum inputs (Ngabe, Bidleman \& Scott, 2000; Ross \& Oros, 2004). 
Other sources include creosote oil leachates, historical industrial sites and tire dust (Bos, Prinsen, van Rooy, Jongeneelen, Theuws \& Henderson, 1987; Takada, Onda \& Ogura, 1990; Walker, Dickhut, Chisholm-Brause, Sylva \& Reddy, 2005). As a group, these compounds are generally considered to be hydrophobic and lipophilic, with $\log \mathrm{K}_{\mathrm{ow}}$ values ranging from 3.31 for bicyclic naphthalene to 6.51 for hexicyclic benzo[ghi]perylene (May, 1980; USEPA, 1982). Consequently, these compounds tend to sorb to suspended particles and sediments where deposit feeding organisms may subsequently bioaccumulate them through ingestion of sediments and/or contact with sediments and pore water.

Recent studies in tidal creek and salt marsh complexes along the South Carolina coast have found comparatively high levels of PAHs in intertidal sediments (mean total PAHs $=3.97 \mu \mathrm{g} / \mathrm{g}$ dry weight, range $=0.12-37.03 \mu \mathrm{g} / \mathrm{g}$ dry weight) within suburbanized, urbanized and industrialized watersheds (Sanger, Holland \& Scott, 1999). Fluoranthene is one of the most common PAHs found in the environment. Sediment concentrations of fluoranthene in South Carolina tidal creeks range from $5.69 \mu \mathrm{g} / \mathrm{g}$ dry weight in creeks that drain urban watersheds (e.g., Vardell Creek) to $0.003 \mu \mathrm{g} / \mathrm{g}$ dry weight in creeks that drain forested or reference watersheds (e.g., Sawmill Creek) (Sanger, Holland \& Scott, 1999).

Estuarine habitats are highly productive and serve as critical nursery and feeding areas for many resident and transient species (Cain \& Dean, 1976; Weinstein, 1979; Wenner \& Beatty, 1993). Benthic infaunal organisms, especially oligochaetes, are abundant in tidal creeks and salt marshes, and are believed to play an important role in coastal food webs. Oligochaetes have a high nutritional value and are a major food item in the diet of juvenile fish and crustaceans (Giere \& Pfannkucke, 1982). Many oligochaetes also contain lipids which are critical for shrimp reproduction (Middleditch, Missler, Ward, McVey, Brown \& Lawrence, 1979). Grass shrimp are also abundant in estuaries (Welsh, 1975) and have been shown to be important in food web dynamics by serving as detritivores, primary consumers and secondary consumers (Bell \& Coull, 1978; Kneib, 1985; Fleeger, Carman, Webb, Hilbun \& Pace, 1999). Although grass shrimp do not feed exclusively on oligochaetes, they do consume both macro- and meiobenthos and seem to feed non-selectively, thereby consuming more of the most dominant taxa (Bell \& Coull, 1978).

The tubificid oligochaete Monopylephorus rubroniveus is the dominant macroinfaunal organism in the upper reaches of tidal creeks in South Carolina (Sanger, 1998; Lerberg, Holland \& Sanger, 2000; Gawle, 2002; Gillett, 2003). Densities of M. rubroniveus can exceed 90,000 individuals $/ \mathrm{m}^{2}$ in some intertidal areas (Lerberg, 1997). Previous laboratory toxicological studies involving $M$. rubroniveus have demonstrated that this species is highly tolerant of fluoranthene, one of the predominant PAH congeners found in the environment. In acute sediment exposures with fluoranthene, the 10-day $\mathrm{LC}_{50}$ for $M$. rubroniveus exceeded $3.91 \mu \mathrm{g} / \mathrm{g}$ dry weight (Weinstein, Sanger \& Holland, 2003). In addition, $M$. rubroniveus has the ability to bioaccumulate large amounts of sediment-associated fluoranthene in its tissues. In the above mentioned study, mean tissue concentrations of fluoranthene were as high as $6,431 \mu \mathrm{g} / \mathrm{g}$ dry weight (Weinstein, Sanger \& Holland, 2003). Using environmentally-relevant sediment concentrations of PAHs (43.2 $\mu \mathrm{g}$ fluoranthene/g dry weight), the laboratory-derived 
biota-sediment accumulation factor (BSAF) for M. rubroniveus was 8.4 (unpublished data).

The high bioaccumulation potential of fluoranthene by $M$. rubroniveus suggests the likelihood for dietary transfer of this compound to predators. This potential could be enhanced by factors that affect rates of biochemical metabolism, such as environmental quality, an organism's physiological status, or chemicals like piperonyl butoxide (PBO). PBO is a competitive inhibitor of cytochrome P-450, and a common additive of thousands of pyrethroid pesticide products used in mosquito control (e.g., Scourge ${ }^{\circledR}$, Anvil ${ }^{\circledR}$ ), agriculture (e.g., Pyrenone ${ }^{\circledR}$ ) and household pest control (e.g., Deep 6 Flea Killer $^{\circledR}$, Raid Ant and Roach Killer ${ }^{\circledR}$ ). Many PAH compounds, including fluoranthene, are metabolized by cytochrome P-450 (Stegeman, Brouwer, DiGiulio, Forlin, Fowler, Sanders \& Van Veld, 1992; Akkanen \& Kukkonen, 2003), thus inhibition of this enzyme by $\mathrm{PBO}$ could result in increased bioaccumulation and dietary transfer of PAHs.

The objectives of the current study were two-fold. First, we wanted to evaluate the potential for dietary transfer of fluoranthene between the oligocheate $(M$. rubroniveus) and a model predator species, the grass shrimp (Palaemonetes pugio). Second, we wanted to investigate the influence of PBO on dietary transfer of fluoranthene between these two species.

\section{Methods}

\subsection{Experimental Overview}

To achieve the objectives of this study, two different experiments were performed. First, the overall sensitivity of grass shrimp, Palaemonetes pugio, to PBO was evaluated using a 96-hour acute toxicity test. Second, a fluoranthene dietary transfer study was conducted using the oligochaete, Monopylephorus rubroniveus, as the prey item and grass shrimp as the predator. Four treatments were performed. Treatment A consisted of PBO-exposed shrimp fed fluoranthene-dosed oligochaetes. Treatment B consisted of control shrimp fed fluoranthene-dosed oligochaetes. Treatment $\mathrm{C}$ consisted of PBO-exposed shrimp fed control oligochaetes. Treatment D consisted of control shrimp fed control oligochaetes (Table 1).

\subsection{Test Organisms}

Grass shrimp for the toxicological test and the dietary transfer experiment were collected with a dip net from Leadenwah Creek on Wadmalaw Island, SC, an unimpacted reference site for PAHs (unpublished data). In the laboratory, shrimp were held for two days in an aerated aquarium and were not fed. Adult shrimp that were free of external parasites or other abnormalities were selected for the experiments.

Oligochaetes for the dietary transfer experiment were obtained from sediment that was collected from the intertidal banks of the upper reach of Okatee Creek, near Bluffton, SC. Sediment was collected in plastic bags, brought back to the laboratory and placed on top of ice in a cooler for four hours. These oligochaetes demonstrate negative taxis to cold and are easily collected from the sediment surface following cold exposure with minimal sieving and sorting required. 


\subsection{Test Compounds}

Technical grade PBO (90\% purity) was obtained from ACROS Organics and was used for the toxicological test and the dietary transfer experiment. Fluoranthene $(98 \%$ purity) was obtained from Sigma-Aldrich and was used to spike sediment in the oligochaete culture for the dietary transfer experiment. Neither PBO nor fluoranthene are soluble in water and ethanol and acetone were used as carriers, respectively.

\subsection{Toxicological Test}

Before its use in the dietary transfer experiment, the toxicity of PBO to grass shrimp was assessed in a 96-hour acute toxicity test. Five nominal concentrations of PBO were tested $(0,250,500,1000$ and $2000 \mu \mathrm{g} / \mathrm{L})$, in addition to an ethanol carrier control. A constant volume of ethanol (equivalent to $0.003 \%$ of total solution volume) was used in all treatments. All treatments were replicated three times. Replicates consisted of 10 grass shrimp in $1000 \mathrm{~mL}$ test beakers. The test beakers were aerated during the experiment and the grass shrimp were not fed. Solutions were renewed every other day. Mortality and water quality parameters were assessed every 24 hours.

\subsection{Oligochaete Dosing}

Fluoranthene-dosed and control oligochaetes for the dietary transfer study were produced by establishing two oligochaete cultures: one culture consisted of fluoranthenespiked sediment and the other culture contained control sediment that was not spiked with fluoranthene. Sediment for both cultures was collected from the intertidal banks of the upper reaches of Okatee Creek (near Bluffton, SC). Upon return to the laboratory, sediment was wet sieved through a $500 \mu \mathrm{m}$ mesh screen, left to settle overnight, drained and frozen to remove any unwanted biota. After 24 hours, sediment was thawed and divided between the two cultures.

For the fluoranthene-spiked culture, $\sim 1.5 \mathrm{~kg}$ wet weight sediment was spiked with $0.029 \mathrm{~g}$ fluoranthene that was dissolved in $5 \mathrm{~mL}$ of acetone. For the control culture, 5 $\mathrm{mL}$ acetone was added to $\sim 1.5 \mathrm{~kg}$ wet weight sediment. Both fluoranthene-spiked and control sediments were rolled overnight uncovered in a $2 \mathrm{~L}$ bottle to allow the acetone to evaporate.

The fluoranthene-spiked and control sediment mixtures were placed in separate glass trays ( $28 \mathrm{~cm} \times 20 \mathrm{~cm} \times 5 \mathrm{~cm}, 1 \times \mathrm{w} \times \mathrm{h})$ and $\sim 1 \mathrm{~L}$ of seawater ( $25 \mathrm{psu}$ ) was added. The sediment and water mixtures were allowed to settle overnight prior to adding the oligochaetes. Oligochaetes were added to the trays two days before the start of the dietary transfer experiment, which allowed the oligochaetes in spiked sediment to bioaccumulate fluoranthene. Previous experiments in our laboratory have demonstrated that $M$. rubroniveus achieves steady state tissue residues of fluoranthene in spiked sediment in $<32 \mathrm{~h}$ (unpublished data).

\subsection{Dietary Transfer Experiment}


Dietary transfer of fluoranthene from oligochaetes to grass shrimp was assessed under control conditions and in seawater fortified with PBO. The basic experimental design consisted of a 5-day feeding (bioaccumulation) period, followed by a 3-day nonfeeding (depuration) period. There were four treatments, as previously described (see Table 1).

Grass shrimp (60 individuals) were held separately in $600 \mathrm{~mL}$ beakers with 500 $\mathrm{mL}$ of seawater (25 psu). Beakers were aerated and covered with screen. PBO-exposed shrimp (treatments A and C) were maintained in seawater fortified with $575 \mu \mathrm{g} \mathrm{PBO} / \mathrm{L}$ (nominal). This concentration of $\mathrm{PBO}$ represented the approximate $\mathrm{LC}_{10}$ value determined from the toxicological study. Grass shrimp were introduced to test conditions one day prior to the start of the experiment for acclimation. During the 5-day feeding period, either 20 fluoranthene-dosed oligochaetes (treatments A and B) or 20 control oligochaetes (treatments $\mathrm{C}$ and D) were fed to each grass shrimp once per day. During the 3-day depuration period, grass shrimp were not fed. In all treatments, water was changed every other day, and water quality parameters were monitored daily (Table 2).

During the feeding period, three grass shrimp in treatments A and B were sampled for fluoranthene tissue residues each day between four and seven hours after feeding, which allowed time for gut clearance (Hoyt, Fleeger, Siebeling \& Feller, 2000). In treatments $\mathrm{C}$ and $\mathrm{D}$, three grass shrimp were sampled only on days 1 and 5 of the feeding period. During the depuration period, three grass shrimp in treatments A and B were sampled for fluoranthene tissue residues each day. Treatments $\mathrm{C}$ and $\mathrm{D}$ were not continued into the depuration phase because no fluoranthene uptake was expected, as these shrimp were only fed control oligochaetes.

\subsection{Analytical Chemistry}

The amount of fluoranthene that was transferred to grass shrimp through the diet was quantified using the following procedure. Grass shrimp were rinsed with deionized water, placed on aluminum foil, allowed to air dry at room temperature in the dark for eight hours and weighed. Fluoranthene was extracted from grass shrimp by grinding them in a Ten Broeck tissue homogenizer with $4 \mathrm{~mL}$ extraction fluid [cyclohexane:acetone (2:1)] and quantified using reverse phase HPLC. Fifty $\mu$ L of sample or standard solution was injected directly onto an Alltech $3.9 \mathrm{~mm} \times 15 \mathrm{~cm}$ alphaBond C18 column. An isocratic elution was performed with acetonitrile:water $(9: 1)$ at $1.0 \mathrm{~mL} / \mathrm{min}$. A Hewlett-Packard 1100 Series Fluorescence Detector was used at an excitation wavelength of $360 \mathrm{~nm}$ with emission detection set at $460 \mathrm{~nm}$. Peaks were recorded and quantified using Agilent ChemStation software (version A.08.03). The limit of detection for fluoranthene was $0.3 \mu \mathrm{g} / \mathrm{L}$, or $15.0 \mathrm{pg}$ total mass. The recovery of fluoranthene in spiked grass shrimp tissue samples was $88.8 \pm 4.0 \%(n=3)$. All fluoranthene tissue residues are reported on a dry weight basis.

Bioaccumulation of fluoranthene in oligochaetes from the sediment cultures was determined for days 1 through 5 of the dietary transfer experiment. Oligochaete tissue residues were determined in a manner generally similar to that described above for grass shrimp with the following exceptions: 1) three oligochaetes were pooled to form one sample, and 2) extractions were performed with only $1 \mathrm{~mL}$ extraction fluid. The recovery of fluoranthene in spiked oligochaete tissue samples was $98.2 \pm 5.5 \%(\mathrm{n}=8)$. 
Fluoranthene concentrations in the sediment cultures were determined by removing $\sim 0.2 \mathrm{~g}$ sediment on days 1 and 5 . Sediment was placed on aluminum foil and allowed to air dry at room temperature in the dark for eight hours. Once dry, the sediment was homogenized using a mortar and pestle, and then $\sim 50 \mathrm{mg}$ of sediment was subsampled and split into two replicate samples. Each sample was sonicated with $4 \mathrm{~mL}$ extraction fluid, centrifuged at $3000 \mathrm{rpm}$ for $20 \mathrm{~min}$ in glass centrifuge tubes, and quantified using reverse phase HPLC as described above for tissue residues. The recovery of fluoranthene in spiked sediment samples was $109.0 \pm 8.3 \%(n=2)$. Sediment concentrations are reported as the mean of the two replicate samples on a dry weight basis.

\subsection{Data Analysis}

For the $\mathrm{PBO}$ acute toxicity test, the 96 -hour $\mathrm{LC}_{50}$ and corresponding $95 \%$ confidence intervals were determined using the trimmed Spearman Karber method $(1.7 \%$ trim) (ToxCalc version 5.0.23). For the dietary transfer experiment, bioaccumulation of fluoranthene in grass shrimp was evaluated with a two-way analysis of variance (ANOVA) and Tukey's honestly significant difference test. The two main effects tested were treatment (only treatments A and B were tested) and day (1 through 5). Grass shrimp depuration rates were evaluated by comparing the linear regression lines of treatments A and B. Results were considered significant at $\alpha \leq 0.05$.

Trophic transfer coefficients (TTCs) were calculated in order to assess whether biomagnification of fluoranthene occurred in the presence and absence of PBO. A TTC is the ratio of contaminant residue in the consumer tissue (grass shrimp) to that in the prey tissue (oligochaete). Biomagnification is judged to take place if the TTC is $>1$ (Suedel, Boraczek, Peddicord, Clifford, \& Dillon, 1994). For this study, TTCs were averaged for each treatment. Water quality data are presented as mean \pm standard deviation (S.D.) and fluoranthene concentrations are expressed as mean \pm standard error (S.E.).

\section{Results}

\subsection{Toxicological Test}

Grass shrimp mortality in both the control and carrier control treatments after 96hours was $1.6 \%$. Mortality to PBO occurred in a concentration-dependent fashion and ranged from $3.3 \%$ at the lowest concentration $(250 \mu \mathrm{g} / \mathrm{L})$ to $100 \%$ at the highest concentration $\left(2000 \mu \mathrm{g} / \mathrm{L}\right.$; Figure 1). The 96 -hour $\mathrm{LC}_{50}$ was $1043 \mu \mathrm{g} / \mathrm{L}(95 \% \mathrm{CI}=915$ $1189 \mu \mathrm{g} / \mathrm{L})$. Water quality parameters remained relatively constant throughout the duration of the test (Table 2).

\subsection{Dietary Transfer Experiment}

Fluoranthene concentrations in the spiked sediment culture were $39.0 \pm 7.5 \mu \mathrm{g} / \mathrm{g}$ and $58.1 \pm 2.5 \mu \mathrm{g} / \mathrm{g}$ dry weight on days 1 and 5 of the dietary transfer experiment, respectively. These concentrations of fluoranthene are similar to the total PAH levels found in tidal creeks with urbanized watersheds (Sanger, Holland \& Scott, 1999). 
Oligochaetes appeared to achieve steady-state tissue residues of fluoranthene after two days of exposure to the spiked sediment during the acclimation period (Figure 2). During the 5-day feeding period, the mean fluoranthene tissue residue in the oligochaetes was $671.6 \pm 32.0 \mu \mathrm{g} / \mathrm{g}$ dry weight. Fluoranthene concentrations in the control culture sediment and the control oligochaetes were below the level of detection on both days 1 and 5.

During the 5-day feeding period, grass shrimp in treatments A and B bioaccumulated fluoranthene in their tissues (Figure 3). Within each treatment, fluoranthene tissue residues did not change over the course of the five feeding days $(\mathrm{p}=$ 0.6110). However, tissue residues were significantly different between treatments and were three times higher in treatment $A$ than treatment $B(p<0.0001)$. Grass shrimp in treatment A (PBO exposed shrimp fed fluoranthene-dosed oligochaetes) had mean fluoranthene tissue residues of $13.9 \pm 1.2 \mu \mathrm{g} / \mathrm{g}$, and grass shrimp in treatment B (control shrimp fed fluoranthene-dosed oligochaetes) had mean fluoranthene tissue residues of 4.9 $\pm 0.9 \mu \mathrm{g} / \mathrm{g}$. The TTCs for dietary transfer of fluoranthene from oligochaetes to grass shrimp were 0.02 and 0.01 in treatments $A$ and $B$, respectively. Grass shrimp in treatments $\mathrm{C}$ and $\mathrm{D}$ were fed control oligochaetes and had comparatively low levels of fluoranthene in their tissues (Figure 4). Mean fluoranthene residues in grass shrimp in treatment $\mathrm{C}$ (PBO exposed shrimp fed control oligochaetes) and D (control shrimp fed control oligochaetes) were $0.07 \pm 0.02 \mu \mathrm{g} / \mathrm{g}$ and $0.03 \pm 0.01 \mu \mathrm{g} / \mathrm{g}$, respectively. These low tissue residues of fluoranthene were probably the result of the volatilization of fluoranthene from the fluoranthene-spiked oligochaete cultures, which were maintained in the same laboratory. Throughout the feeding experiment, mortality in grass shrimp was low (1.6\%) and water quality parameters remained relatively constant (Table 2 ).

During the 3-day depuration period, mean fluoranthene tissue residues in grass shrimp from treatments A and B decreased in a time-dependent fashion (Figure 5). Over the three day period, fluoranthene tissue residues in grass shrimp decreased by $80.9 \%$ and $72.9 \%$ in treatments $\mathrm{A}$ and $\mathrm{B}$, respectively. The rate of depuration was significantly faster in treatment $\mathrm{A}$ (slope $=-3.12 \mu \mathrm{g}$ fluoranthene/g/day) than in treatment B (slope = $1.79 \mu \mathrm{g}$ fluoranthene/g/day) $(\mathrm{p}=0.0300)$. However, at the end of the three day depuration period, mean fluoranthene tissue residues from grass shrimp in treatment $\mathrm{A}$ were still $\sim 25$ times higher than treatment B.

\section{Discussion}

The results of the present study demonstrate that PAHs in estuarine sediments can be transferred from benthic infauna to shrimp through dietary transfer. Grass shrimp in this study bioaccumulated fluoranthene from a diet of oligochaete worms that had been cultured in fluoranthene-spiked sediments. These results corroborate those of previous studies in marine systems which have demonstrated that sediment-associated PAHs can be transferred to bottom-feeding organisms through the diet. For example, winter flounder (Pseudopleuronectes americanus) fed polychaetes (Nereis virens) dosed with benzo[a]pyrene accumulated both the parent compound and its metabolites (McElroy \& Sisson, 1989). Other studies have demonstrated that waterborne PAHs can also be transferred in the diet. Rotifers (Brachionis plicatilis) fed algae (Isochrysis galbana) cultured in phenanthrene-dosed water bioaccumulated phenanthrene in their tissues (Wolfe, Schwartz, Singaram, Mielbrecht, Tjeerdema \& Sowby, 1999). Likewise, clams 
(Mercenaria mercenaria) fed diatoms (Thalassiosira pseudomana) cultured in benzo[a]pyrene-spiked water bioaccumulated that PAH in their tissues (Dobroski \& Epifano, 1980). In fact, these authors concluded that dietary transfer and direct uptake from water contributed equally to body burdens of benzo[a]pyrene in clams. This suggests that dietary uptake can, in some cases, be a significant contributor to overall PAH tissue residues in consumers.

The presence of the metabolic inhibitor, $\mathrm{PBO}$, in the water resulted in a three-fold increase in the bioaccumulation of fluoranthene in grass shrimp, demonstrating that PBO enhanced the dietary uptake of fluoranthene. PBO is a general cytochrome P-450 inhibitor and is commonly used as a synergist in synthetic pyrethroid pesticide formulations (Osimitz \& Breathnach, 2001). In pyrethroid formulations, PBO impedes the oxidative breakdown ability of cytochrome P-450, which reduces biotransformation and allows the pesticides to accumulate to lethal levels. In addition to pesticides, cytochrome P-450 is also responsible for the metabolism of PAHs in vertebrate and invertebrate species (Stegeman, Brouwer, DiGiulio, Forlin, Fowler, Sanders, et al., 1992; James. 1989; James \& Boyle, 1998). Biotransformation of PAHs naturally occurs at a slower rate in invertebrates than vertebrates due to lower concentrations of cytochrome P450 (James, 1989; James \& Boyle, 1998; Lee, 1998). These rates of transformation are further reduced by the presence of metabolic inhibitors like PBO. Water fleas (Daphnia magna) exposed to $\mathrm{PBO}$ exhibited a reduction in the biotransformation of pyrene, which was likely mediated through an inhibition of cytochrome P-450 (Akkanen \& Kukkonen, 2003). In the current study, increased bioaccumulation of fluoranthene in PBO-exposed grass shrimp was also likely the result of an inhibition of cytochrome P-450 and subsequent reduction in the rate of fluoranthene biotransformation, although this was not directly measured. Nevertheless, the results of the current study support the notion that cytochrome P-450 plays an important role in the metabolism of PAHs in crustaceans.

Exposure to PBO during the accumulation period also influenced fluoranthene depuration kinetics in grass shrimp. Depuration rates were significantly higher in the PBO-exposed grass shrimp than in control grass shrimp, suggesting a rapid recovery of those cytochrome P-450 isozymes that had been inhibited during the accumulation period. Despite the faster rate of depuration, $\mathrm{PBO}$-exposed grass shrimp had significantly higher levels of fluoranthene in their tissues at the end of the 3-day depuration period relative to control shrimp, whose fluoranthene tissue residues were similar to background levels. The continued presence of fluoranthene in the PBO-exposed grass shrimp could have profound physiological implications for dose-and time-dependent responses, such as DNA strand breaks (Lee, Maruya \& Bulski, 2004) and UV-enhanced photosensitization reactions (Weinstein, 2003). Also, the continued presence of fluoranthene in the grass shrimp tissues increases the likelihood that fluoranthene could be transferred to higher trophic levels through the diet. The physiological and ecological implications of lingering fluoranthene residues in PBO-exposed organisms certainly warrant further investigation.

The acute toxicity of PBO has been evaluated in a variety of aquatic species, and these studies have demonstrated that invertebrates are generally more sensitive to PBO than fish (Osimitz \& Hobson, 1998). Previous studies involving invertebrates have demonstrated that $\mathrm{PBO}$ is highly toxic, with reported $\mathrm{LC}_{50}$ values for water fleas (Ceriodaphnia dubia) and amphipods (Hyalella azteca) of $330 \mu \mathrm{g} / \mathrm{L}$ and $530 \mu \mathrm{g} / \mathrm{L}$, 
respectively (Baily, Digiorgio, Kroll, Miller, Hinton \& Starrett, 1996; Ankley \& Collyard, 1995). By comparison, studies involving fish have demonstrated that $\mathrm{PBO}$ is only moderately toxic to this taxon, with reported $\mathrm{LC}_{50}$ values ranging from $3,940 \mu \mathrm{g} / \mathrm{L}$ in sheepshead minnow (Cyprinodon variegatus) to $11,200 \mu \mathrm{g} / \mathrm{L}$ in rainbow trout (Salmo gairdneri) (Erickson, Goodrich \& Lech, 1988). The results of the current study suggest that grass shrimp $\left(\mathrm{LC}_{50}=1,043 \mu \mathrm{g} / \mathrm{L}\right)$ are somewhat less sensitive to PBO compared to previously tested invertebrate species, but are not as tolerant as previously tested fish species. This finding is corroborated by a study involving freshwater prawns (Palaemon paucidens), which reported an $\mathrm{LC}_{50}$ value of 3,500 $\mu \mathrm{g} / \mathrm{L}$ (Kobayashi, Wang, Imada, Oshima \& Rompas, 1993).

Despite the fact that fluoranthene bioaccumulation was observed in grass shrimp that were fed fluoranthene-dosed oligochaetes, the calculated TTCs suggest that biomagnification of fluoranthene in the food chain is unlikely. Biomagnification is likely to occur when the TTC values in predator-prey relationships are $>1.0$ (Suedel, Boraczek, Peddicord, Clifford \& Dillon, 1994). In the current study, TTC values between grass shrimp and oligochaete worms were 0.02 and 0.01 in the presence and absence of $\mathrm{PBO}$, respectively, or 50 to 100 -fold less than those values associated with biomagnification. In a previous field study investigating dietary transfer of PAHs between zooplankton and mussels (Mytilus edulis) Broman, Naf, Lundbergh and Zebuhr (1990) reported TTC values of $0.2,0.3$ and 0.6 for phenanthrene, fluoranthene and anthracene, respectively. These TTC values, which are higher than those reported in the current study, are probably a reflection of the limited activity of cytochrome P-450 isozymes and other mixedfunction oxygenases in molluscs compared to crustaceans (Livingstone, 1991). Nevertheless, these results collectively suggest that the potential for biomagnification of PAHs in aquatic food webs is low.

Despite its widespread use in household and agricultural pesticides and mosquito adulticides, few attempts have been made to measure concentrations of PBO in the environment (Osimitz \& Breathnach, 2001). Application rates of PBO range from $0.0036 \mathrm{lb} /$ acre and $0.021 \mathrm{lb} /$ acre in mosquitocide formulations (Anvil ${ }^{\circledR}$ and Scourge ${ }^{\circledR}$, respectively) (Bayer Environmental Science, 2002; Clarke Mosquito Control Products, $2005)$ to $0.037 \mathrm{lb} /$ acre in certain agricultural products (Kenega, 1973). Immediately following mosquito spraying, PBO has been detected in surface water at concentrations ranging from 0.7 to $15,000 \mathrm{ng} / \mathrm{L}$ (Zulkosky, Ruggieri, Terracciano, Brownawell \& McElroy, 2005; Amweg, Weston, Johnson, You \& Lydy, 2006). Water samples collected from urban creeks, where household pesticides may have been applied, generally had undetectable levels of PBO (Amweg, Weston, Johnson, You \& Lydy, 2006). At these concentrations, PBO itself is not particularly toxic; however, it has the potential to increase the toxicity of other compounds. Under most natural conditions, PBO is relatively short-lived with half-lives in the water column and sediments of 1.6 days and 24 days, respectively (Arnold, 1998). However, under certain conditions, including the absence of light and/or the absence of oxygen, PBO is extremely stable with half-lives in water and sediments that exceeded one year (Arnold, 1998). Given that tidal creek-salt marsh systems can occasionally be light and oxygen-limited, future studies investigating the prevalence and persistence of $\mathrm{PBO}$ in the estuarine environment is warranted.

\section{Conclusion}


This study demonstrates that environmentally-relevant sediment concentrations of fluoranthene can travel through trophic pathways to predatory species in tidal creek and salt marsh complexes of the Southeastern U.S. The oligochaete Monopylephorus rubroniveus is the most abundant macroinfaunal organism in intertidal creeks and has a high toxicological tolerance to fluoranthene, and likely other PAHs. In general, oligochaetes, and other invertebrates, have lower levels of cytochrome P-450 and cannot rapidly metabolize and eliminate PAHs (Lee, 1998). As such, oligochaetes can accumulate relatively high levels of contaminants and can pass them on to primary consumers, including crustaceans and demersal fish. The presence of metabolic inhibitors, like PBO, can enhance the dietary transfer of PAHs. However, dietary transfer as a mechanism of PAH bioaccumulation in estuarine food webs is probably limited to these primary consumers, due to their higher metabolic capacities for removing contaminants from body tissues.

\section{Acknowledgements}

This research was sponsored by the NOAA Center for Sponsored Coastal Ocean Research/Coastal Ocean Program, through the South Carolina Sea Grant Consortium, pursuant to National Oceanic and Atmospheric Administration Award No.

NA960PO113. The authors are grateful to Fred Holland, Chrissy Smith and Keane Phillips for their assistance in this research. This article is contribution number 291 from the Grice Marine Laboratory at the College of Charleston.

\section{References}

Akkanen. J. \& Kukkonen, J.V.K. (2003). Biotransformation and bioconcentration of pyrene in Daphnia magna. Aquatic Toxicology, 64, 53-61.

Amweg, E.L., Weston, D.P., Johnson, C.S., You, J. \& Lydy, M.J. 2006. Effect of piperonyl butoxide on permethrin toxicity in the amphipod Hyalella azteca.

Environmental Toxicology \& Chemistry, 25(7), 1817-1825.

Ankley, G.T. \& Collyard, S.A. (1995). Influence of piperonyl butoxide on the toxicity of organophosphate insecticides to three species of freshwater benthic invertebrates. Comparative Biochemistry \& Physiology, 110C, 149-155.

Arnold, D.J. (1998). The fate and behavior of piperonyl butoxide in the environment. In D.G. Jones, Piperonyl Butoxide: The Insecticide Synergist (pp. 105-120). San Diego: Academic Press.

Baily, H.C., Digiorgio, C., Kroll, K., Miller, J.L., Hinton, D.E. \& Starrett, G. (1996). Development of procedures for identifying pesticide toxicity in ambient waters: Carbofuran, diazinon, chlorpyrifos. Environmental Toxicology \& Chemistry. 15, 837845.

Bayer Environmental Science. (2002). Scourge ${ }^{\circledR}$ Insecticide with SBP-1382 ${ }^{\circledR} /$ Piperonyl Butoxide 4\% $+12 \%$ MF Formula II. Product Label. Bayer Crop Science, Montvale, NJ. 
Bell, S.S. \& Coull, B.C. (1978). Field evidence that shrimp predation regulates meiofauna. Oceologia, 35, 141-148.

Bos, R.P., Prinsen, W.J.C., van Rooy, J.G.M., Jongeneelen, F.J., Theuws, J.L.G. \& Henderson, P.T.H. (1987). Fluoranthene, a volatile mutagenic compound, present in creosote and coal tar. Mutation Research, 187, 119-125.

Broman, D., Naf, C., Lundbergh, I. \& Zebuhr, Y. (1990). An in situ study on the distribution, biotransformation and flux of polycyclic aromatic hydrocarbons (PAHs) in an aquatic food chain (seston-Mytilus edulis L-Somateria mollissima L) from the Baltic: An ecotoxicological perspective. Environmental Toxicology \& Chemistry, 9, 429-442.

Cain, R.L. \& Dean, J.M. (1976). Annual occurrence, abundance, and diversity of fish in a South Carolina intertidal creek. Marine Biology, 36, 369-379.

Clarke Mosquito Control Products. (2005). Anvil ${ }^{\circledR} 10+10$ ULV. Product Label. Clarke Mosquito Control Products, Inc., Roselle, IL.

Dobroski, C.J. \& Epifano, C.E. (1980). Accumulation of benzo[a]pyrene in a larval bivalve via trophic transfer. Canadian Journal of Fisheries and Aquatic Sciences, 37, 2318-2322.

Erickson, D.A., Goodrich, M.S. \& Lech, J.J. (1988). The effect of piperonyl butoxide on hepatic cytochrome P-450 dependent monooxygenase activities in rainbow trout (Salmo gairdneri). Toxicology \& Applied Pharmacology, 94, 1-10.

Fleeger, J.W., Carman, K.R., Webb, S., Hilbun, N. \& Pace, M.C. (1999). Consumption of microalgae by the grass shrimp Palaemonetes pugio. Journal of Crustacean Biology, 19(2), 324-336.

Gawle, C.P. (2002). Tidal creek responses to watershed development: A comparison of summer 1994 and winter 2000 data. Master's Thesis. University of Charleston. Charleston, South Carolina.

Giere, O. \& Pfannkuche, O. (1982). Biology and ecology of marine oligochaeta. A review. Oceanography \& Marine Biology Annual Review, 20, 173-308.

Gillett, D.J. (2003). Ecology of tidal creek oligochaetes: Changes in abundance and secondary production of the numerically dominant species Monopylephorus rubroniveus (Levinson, 1884). Master's Thesis. University of Charleston. Charleston, South Carolina.

Hoyt, M., Fleeger, J.W., Siebeling, R. \& Feller, R.J. (2000). Serological estimation of prey protein gut residence time and quantification of meal size for grass shrimp 
consuming meiofaunal copepods. Journal of Experimental Marine Biology \& Ecology, 248(1), 105-119.

James, M.O. (1989). Cytochrome P450 monooxygenases in crustaceans. Xenobiotica, 19(10), 1063-1076.

James, M.O. \& Boyle, S.M. (1998). Review: Cytochromes P450 in crustacea. Comparative Biochemistry and Physiology Part C, 121, 157-172.

Kenega, E.E. (1973). Factors to be considered in the evaluation of the toxicity of pesticides to birds in their environment. In T.B. Griffin \& J.H. Knelson, Environmental Quality and Safety, vol. II (pp. 166-181). New York: Academic Press.

Kneib, R.T. (1985). Predation and disturbance by grass shrimp, Palaemonetes pugio Holthuis, in soft-substratum benthic invertebrate assemblages. Journal of Experimental Marine Biology \& Ecology, 93, 91-102.

Kobayashi, D., Wang, Y., Imada, N., Oshima, Y. \& Rompas, R.M. (1993). Reduction of the toxicity of fenitrothion to prawns by piperonyl butoxide. Bulletin of the Japanese Society of Scientific Fisheries, 59, 717-720.

Lee, R.F. (1998). Review: Annelid cytochrome P-450. Comparative Biochemistry and Physiology Part C, 121, 173-179.

Lee, R.F., Maruya, K.A. \& Bulski, K. (2004). Exposure of grass shrimp to sediments receiving highway runoff: Effects on reproduction and DNA. Marine Environmental Research, 58, 713-717.

Lerberg, S.B. (1997). Effects of watershed development on macrobenthic communities in the tidal creeks of the Charleston Harbor Estuary. Master's Thesis. University of Charleston. Charleston, South Carolina.

Lerberg, S.B., Holland, A.F. \& Sanger, D.M. (2000). Responses of tidal creek macrobenthic communities to the effects of watershed development. Estuaries, 23(6), 838-853.

Livingstone, D.R. (1991). Cytochrome P-450 and oxidative metabolism in invertebrates. Biochemical Society Transactions, 18, 15-19.

McElroy, A.E. \& Sisson, J.D. (1989). Trophic transfer of benzo[a]pyrene metabolites between benthic marine organisms. Marine Environmental Research, 28, 265-269.

May, W.E. (1980). The solubility of polycyclic aromatic hydrocarbons in aqueous systems. Advanced Chemistry Series, 185, 143-192. 
Middleditch, B.S., Missler, S.R., Ward, D.G., McVey, J.B., Brown, A. \& Lawrence, A.L. (1979). Maturation of Penaeid shrimp: Dietary fatty acids. Proceedings of the World Mariculture Society, 10, 472-476.

Ngabe, B., Bidleman, T.F. \& Scott, G.I. (2000). Polycyclic aromatic hydrocarbons in storm water runoff from urban and coastal South Carolina. The Science of the Total Environment, 255, 1-9.

Osimitz, T.G. \& Breathnach, R. (2001). The safety assessment of piperonyl butoxide. In R. Krieger, Handbook of Pesticide Toxicology: Volume 2 Agents. San Diego: Academic Press.

Osimitz, T.G. \& Hobson, J.F. (1998). An ecological risk assessment of piperonyl butoxide. In D.G. Jones, Piperonyl Butoxide: The Insecticide Synergist (pp. 121-136). San Diego: Academic Press.

Ross, J.R.M. \& Oros, D.R. (2004). Polycyclic aromatic hydrocarbons in the San Francisco Estuary water column: Sources, spatial distributions and temporal trends (1993-2001). Chemosphere, 57, 909-920.

Sanger, D.M. (1998). Physical, chemical and biological environmental quality of tidal creeks and salt marshes in South Carolina estuaries. Ph.D. Dissertation. University of South Carolina. Columbia, South Carolina.

Sanger, D.M., Holland, A.F. \& Scott, G.I. (1999). Tidal creek and salt marsh sediments in South Carolina coastal estuaries: I. Distribution of trace metals. Archives of Environmental Contamination \& Toxicology, 37, 445-457.

Stegeman, J.J., Brouwer, M., DiGiulio, R.T., Forlin, L., Fowler, B.A., Sanders, B.M. \& Van Veld, P.A. (1992). Molecular responses to environmental contamination: Enzyme and protein systems as indicators of chemical exposure and effect. In R.J. Hugett, Biomarkers: Biochemical, physiological, and histological markers of anthropogenic stress. Boca Raton: Lewis Publisher.

Suedel, B.C., Boraczek, J.A., Peddicord, R.K., Clifford, P.A. \& Dillon, T.M. (1994). Trophic transfer and biomagnification potential of contaminants in aquatic ecosystems. Reviews of Environmental Contamination \& Toxicology, 136, 21-89.

Takada, H., Onda, T. \& Ogura, N. (1990). Determination of polycyclic aromatic hydrocarbons in urban street dusts and their source materials by capillary gas chromatography. Environmental Science \& Technology, 8, 1175-1185.

U.S. EPA. (1982). Aquatic fate process data for organic priority pollutants. EPA 440/481-014. Technical Report. Office of Water. Washington, D.C. 
Walker, S.E., Dickhut, R.M., Chisholm-Brause, C., Sylva, S. \& Reddy, C.M. (2005). Molecular and isotopic identification of PAH sources in a highly industrialized urban estuary. Organic Geochemistry, 36, 619-632.

Weinstein, J.E. (2003). Influence of salinity on the bioaccumulation and photoinduced toxicity of fluoranthene to an estuarine shrimp and oligochaete. Environmental Toxicology \& Chemistry, 22, 2932-2939.

Weinstein, J.E., Sanger, D.M. \& Holland, A.F. (2003). Bioaccumulation and toxicity of fluoranthene in the estuarine oligochaete Monopylephorus rubroniveus. Ecotoxicology \& Environmental Safety, 55, 278-286.

Weinstein, M.P. (1979). Shallow marsh habitats as primary nurseries for fishes and shellfish, Cape Fear, North Carolina. Fishery Bulletin, 58, 227-243.

Welsh, B. (1975). The role of grass shrimp (Palaemonetes pugio) in a tidal marsh ecosystem. Ecology, 56, 513-530.

Wenner, E.L. \& Beatty, H.R. (1993). Utilization of shallow estuarine habitats in South Carolina, USA, by postlarval and juvenile stages of Penaeus spp. (Decapoda: Penaeidae). Journal of Crustacean Biology, 13(2), 280-295.

Wolfe, M.F., Schwartz, G.J.B., Singaram, S., Mielbrecht, E.E., Tjeerdema, R.S. \& Sowby, M.L. (1999). Influence of dispersants on the bioavailability and trophic transfer of phenanthrene to algae and rotifers. Aquatic Toxicology, 48, 13-24.

Zulkosky, A.M., Ruggieri, J.P., Terracciano, S.A., Brownawell, B.J \& McElroy, A.E. 2005. Acute toxicity of resmethrin, malathion and methoprene to larval and juveline American lobsters and analysis of pesticide levels in surface waters after Scourge ${ }^{\mathrm{TM}}$, Anvil $^{\mathrm{TM}}$ and Altosid ${ }^{\mathrm{TM}}$ application. Journal of Shellfish Research, 24, 795-804. 
Table 1: Experimental design used in dietary transfer experiment involving grass shrimp

\begin{tabular}{ccccc}
\hline Treatment & Oligochaete Diet & Water Exposure & $\begin{array}{c}\text { Total } \\
\text { Number } \\
\text { Exposed }\end{array}$ & Sampled \\
\hline \hline A & fluoranthene-dosed & $750 \mu \mathrm{g} \mathrm{PBO} / \mathrm{L}$ & 24 & $\begin{array}{c}\text { Uptake: Days 1-5 } \\
\text { Depuration: Days 6-8 }\end{array}$ \\
\hline B & fluoranthene-dosed & control & 24 & $\begin{array}{l}\text { Uptake: Days 1-5 } \\
\text { Depuration: Days 6-8 }\end{array}$ \\
\hline C & control & $750 \mu \mathrm{g} \mathrm{PBO} / \mathrm{L}$ & 6 & Uptake: Days 1 and 5 \\
\hline D & control & control & 6 & Uptake: Days 1 and 5 \\
\hline
\end{tabular}


Table 2: Summary of water quality parameters from 96-h piperonyl butoxide (PBO) toxicological test and 8-day dietary transfer experiment. Values are reported as means $\underline{ \pm}$ standard deviations.

\begin{tabular}{ccccc}
\hline Experiment & Temperature $\left({ }^{\circ} \mathbf{C}\right)$ & Salinity (psu) & $\begin{array}{c}\mathbf{p H} \\
\text { (standard units) }\end{array}$ & $\begin{array}{c}\text { Dissolved Oxygen } \\
(\mathbf{m g} / \mathbf{L})\end{array}$ \\
\hline \hline $\begin{array}{c}\text { PBO Toxicological } \\
\text { Test }\end{array}$ & $21.0( \pm 0.6)$ & $26.9( \pm 1.3)$ & $7.9( \pm 0.1)$ & $6.6( \pm 0.7)$ \\
\hline Dietary Transfer & $21.8( \pm 1.0)$ & $26.6( \pm 1.4)$ & $7.9( \pm 0.1)$ & $5.8( \pm 0.7)$ \\
\hline
\end{tabular}




\section{Figure Captions}

Figure 1. Percent mortality of grass shrimp (Palaemonetes pugio) following a 96-hour aqueous exposure to piperonyl butoxide (PBO). Error bars represent 1 standard error.

Figure 2. Mean concentration of fluoranthene ( $\mu \mathrm{g}$ FLU/g) in whole tissues of fluoranthene-dosed oligochaetes (Monopylephorus rubroniveus) fed to grass shrimp during the 5-day bioaccumulation period. Error bars represent 1 standard error.

Figure 3. Mean concentration of fluoranthene ( $\mu \mathrm{g} \mathrm{FLU/g)} \mathrm{in} \mathrm{whole} \mathrm{tissues} \mathrm{of} \mathrm{grass}$ shrimp (Palaemonetes pugio) that were fed fluoranthene-dosed oligochaetes. Grass shrimp in Treatment A were exposed to piperonyl butoxide (PBO) and had significantly higher fluoranthene tissue residues $(\mathrm{p}>0.0001)$. Error bars represent 1 standard error.

Figure 4. Mean concentration of fluoranthene ( $\mu \mathrm{g} \mathrm{FLU} / \mathrm{g})$ in whole tissues of grass shrimp (Palaemonetes pugio) that were fed control oligochaetes. Grass shrimp in Treatment $\mathrm{C}$ were exposed to piperonyl butoxide (PBO). Error bars represent 1 standard error.

Figure 5. Mean concentration of fluoranthene ( $\mu \mathrm{g} \mathrm{FLU} / \mathrm{g}$ ) in whole tissues of grass shrimp (Palaemonetes pugio) during the last day of uptake (U5) and three days of depuration (D1 - D3). Grass shrimp in Treatment A were exposed to piperonyl butoxide (PBO). Error bars represent 1 standard error. 
Filipowicz_Figure_1

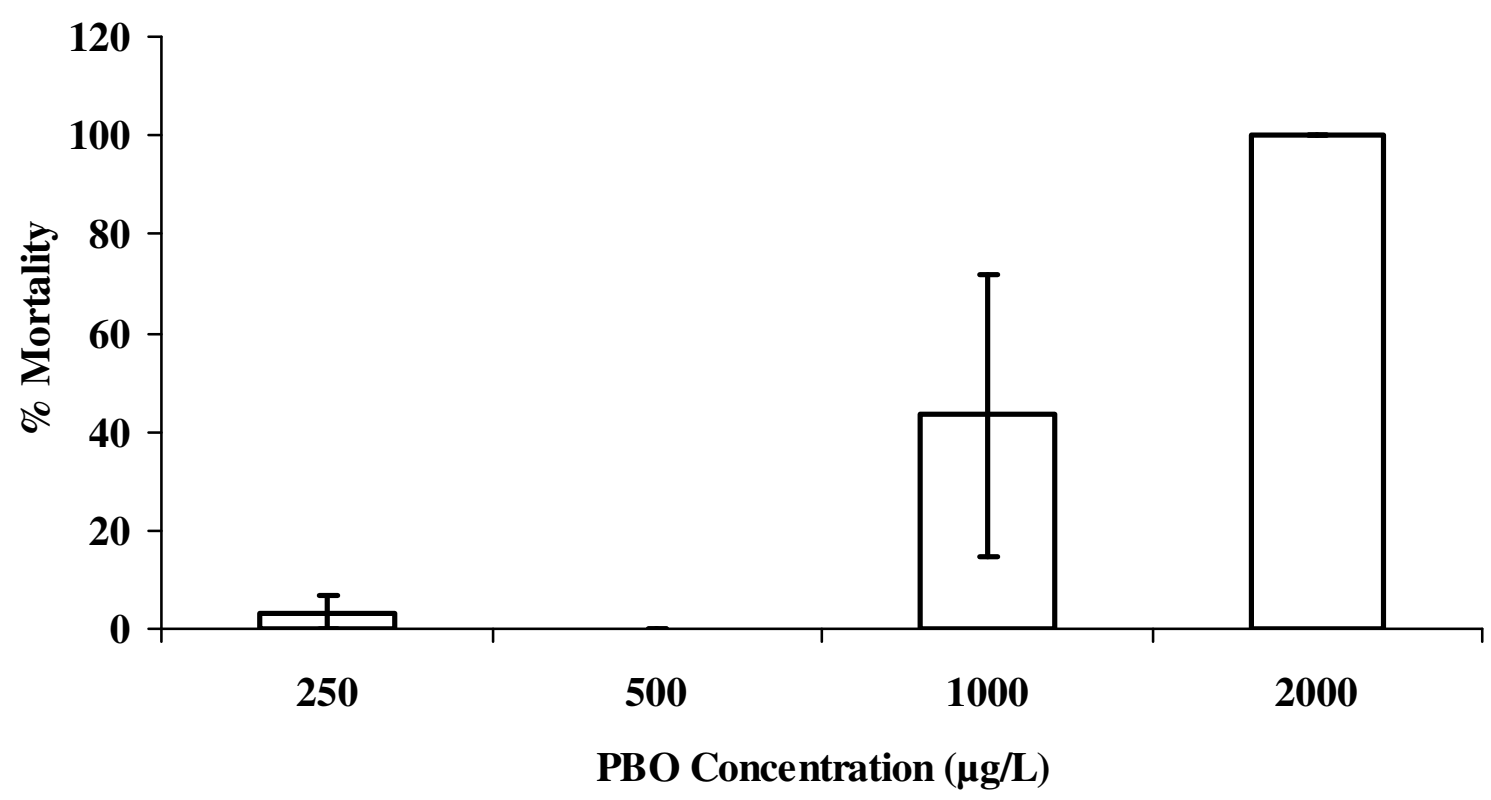


Filipowicz_Figure_2

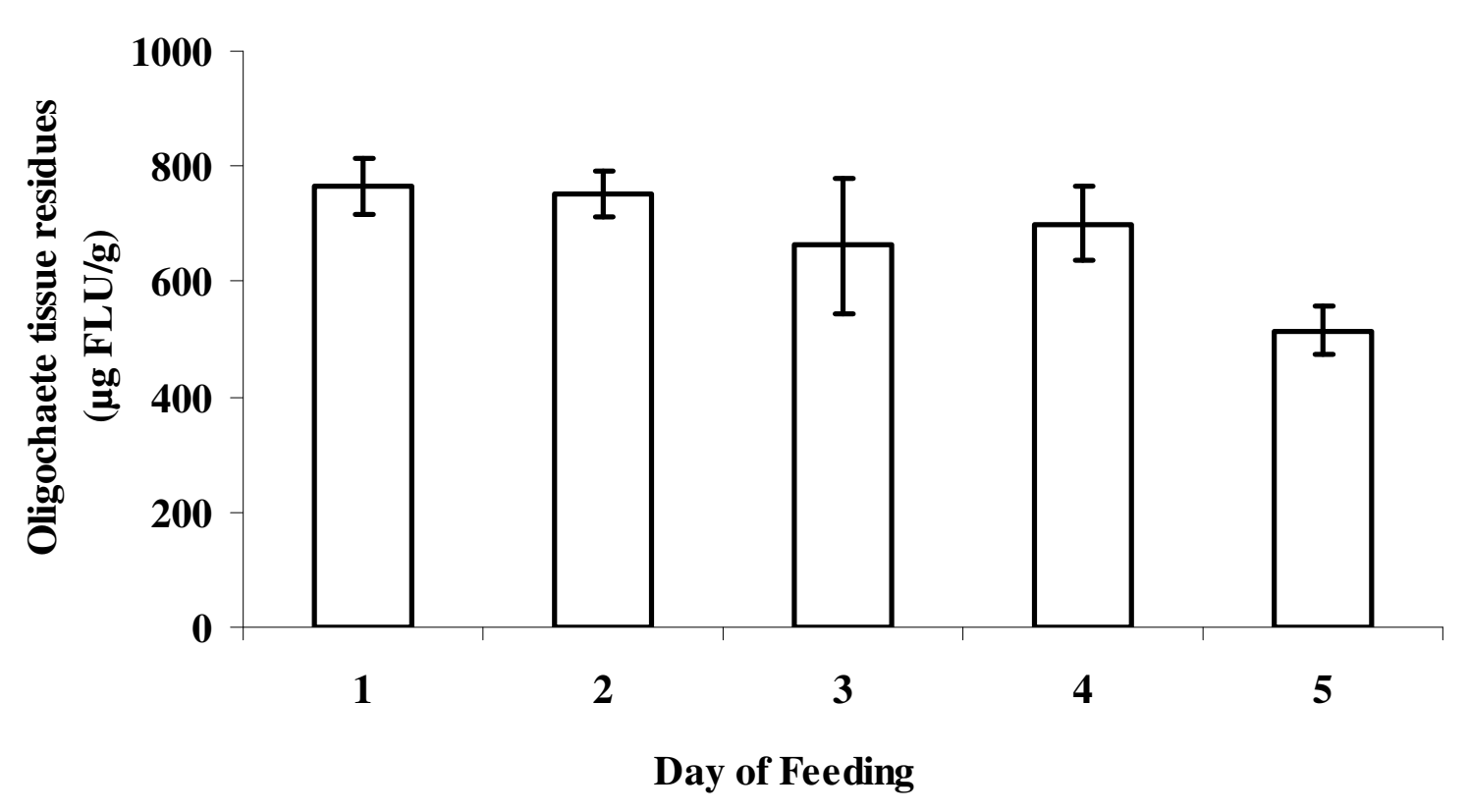


Filipowicz_Figure_3

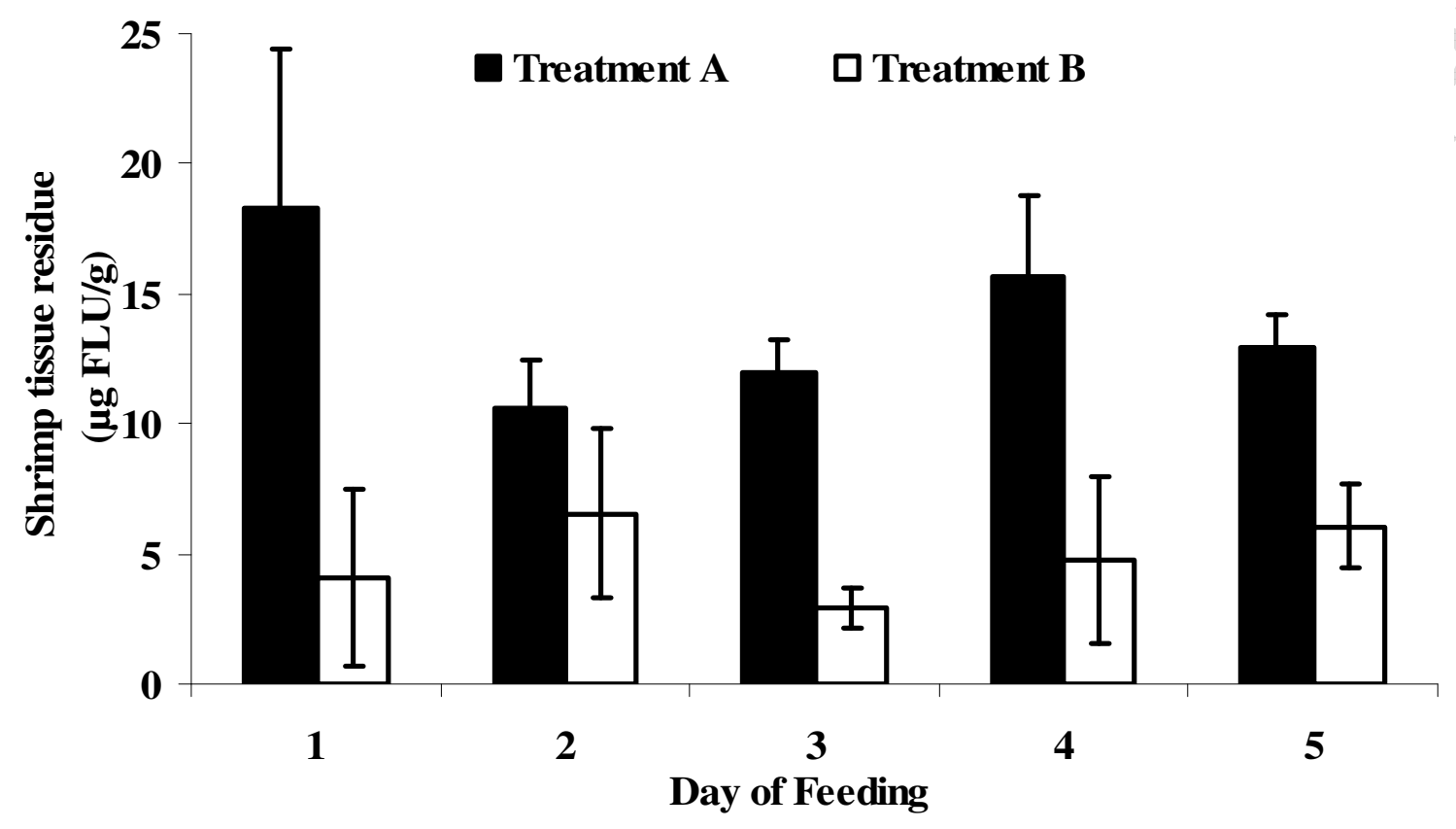


Filipowicz_Figure_4

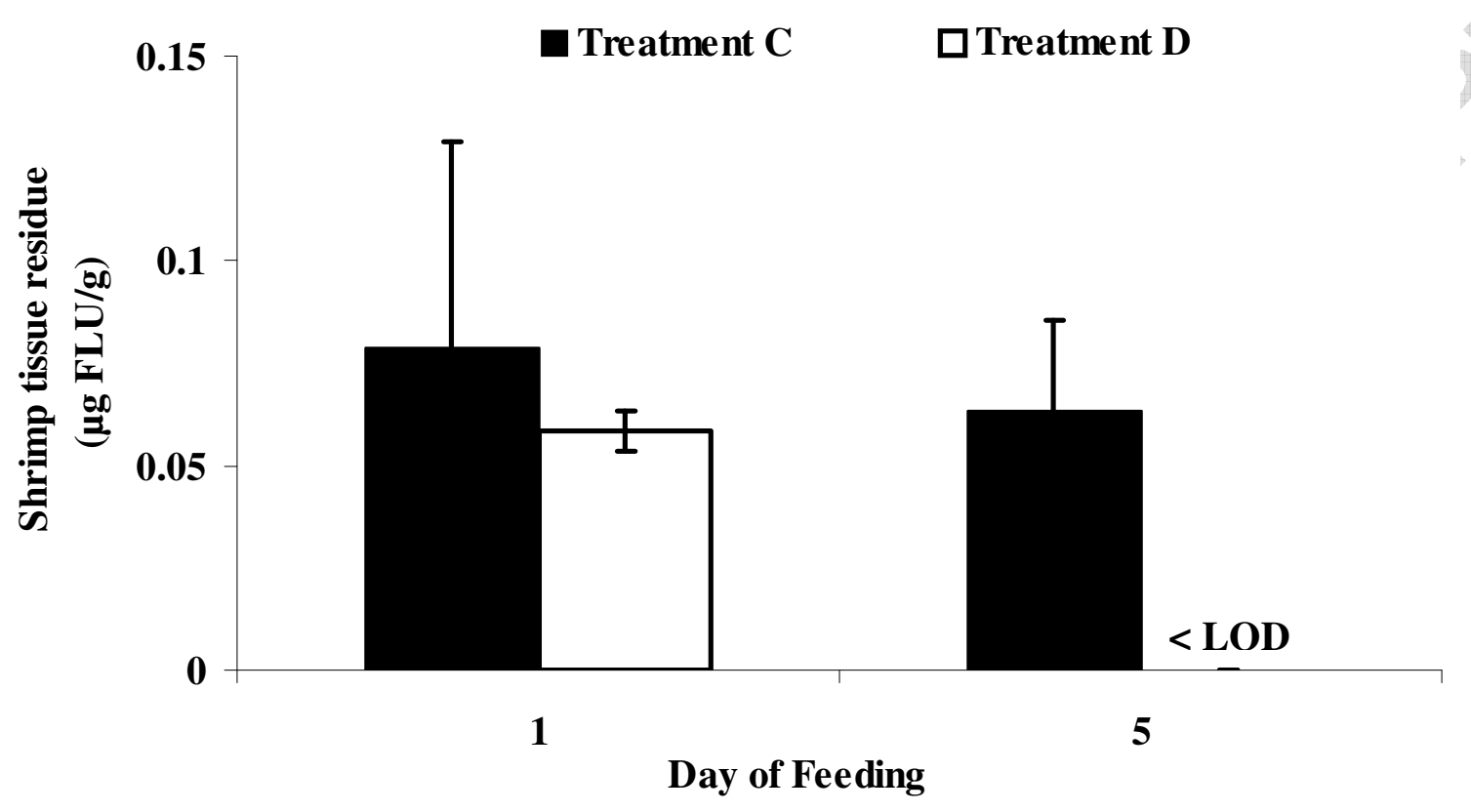


Filipowicz_Figure_5

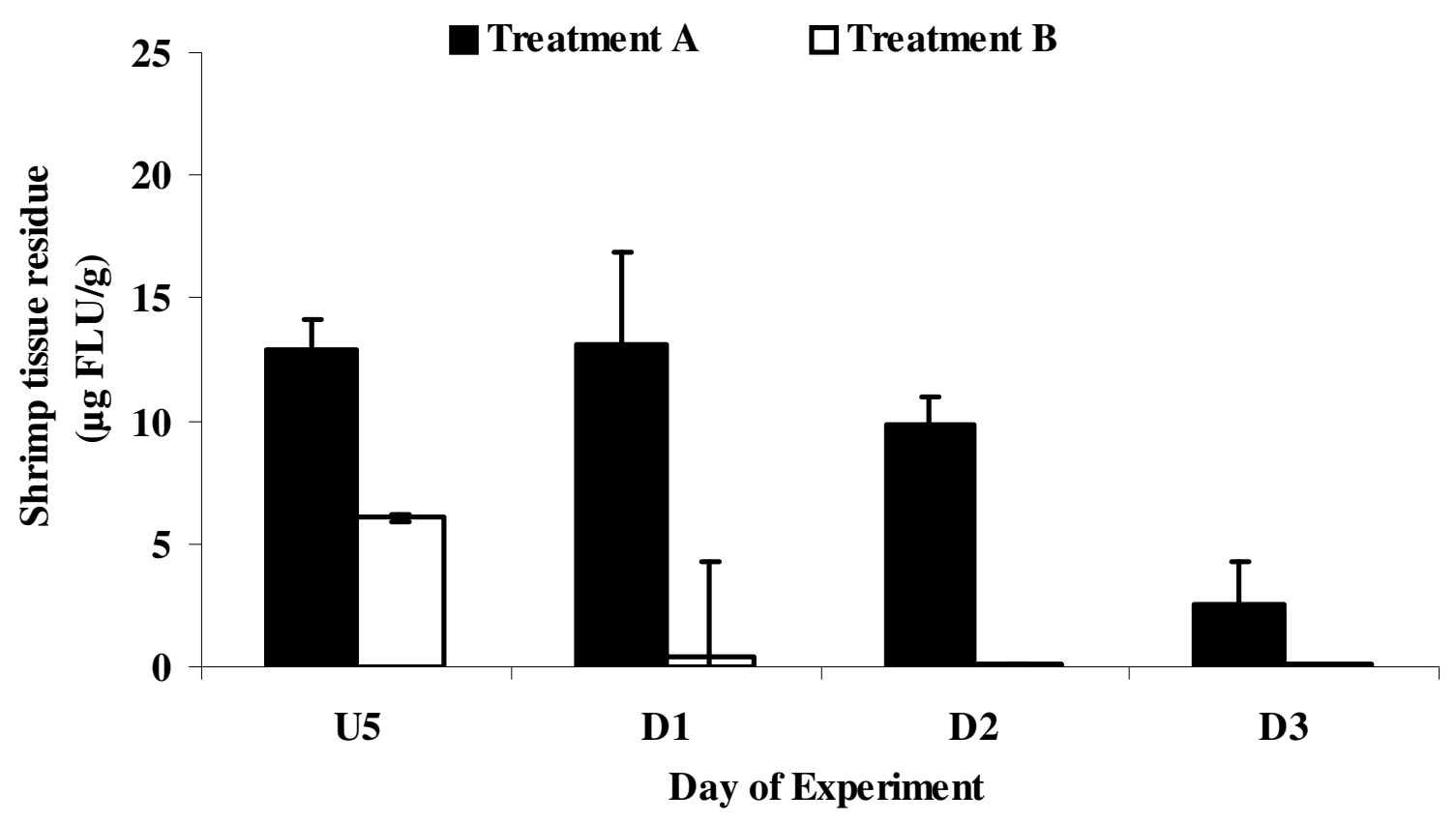

